\title{
Stunting of the penis in Heleobia parchappii (Mollusca: Cochliopidae) and its relationship with parasitism
}

\author{
Matías J. Merlo*, Manuela Parietti, Jorge A. Etchegoin \\ Laboratorio de Parasitología, Facultad de Ciencias Exactas y Naturales, Universidad Nacional de Mar del Plata (UNMdP), \\ Consejo Nacional de Investigaciones Científicas y Técnicas (CONICET), Mar del Plata (B7602AYL), Argentina
}

\begin{abstract}
Penis anatomy is used to discriminate species of gastropods belonging to the family Cochliopidae; however, this characteristic may be affected by the presence of parasites. To evaluate the possible effect of parasites on penis length and number of papillae in Heleobia parchappii, 195 males were collected from the Nahuel Rucá Lagoon, Argentina. Male snails were only infected by trematode digeneans (total prevalence $45.13 \%$ ). Three out of 9 species of digeneans registered showed prevalence values higher than $10 \%$ : Microphallus szidati, M. simillimus, and Notocotylidae sp. 1. The penis length of non-parasitized males and those parasitized by M. szidati and $M$. similimus increased with increased snail length; however, this increase was lower in infected snails. In the case of snails infected with Notocotylidae sp. 1, no relationship between shell length and penis length was apparent. Differences in the life cycles of these 3 digeneans could explain the null or lower penis growth rate in relation to host body growth. In contrast, no change was observed in the number of penial papillae of $H$. parchappii when these snails were infected by larval digeneans compared to those that were not infected. This indicates that penial papillae may be a more stable characteristic than penis length to discriminate between species within the Cochliopidae. The study of penial papillae should be central in the taxonomy and identification of new species within the Cochliopidae, as well as in previously described species.
\end{abstract}

KEY WORDS: Digenean $\cdot$ Penis morphology $\cdot$ Penial papillae $\cdot$ Microphallus szidati $\cdot$ Microphallus simillimus $\cdot$ Notocotylidae

Resale or republication not permitted without written consent of the publisher

\section{INTRODUCTION}

Gastropod species belonging to the genus Heleobia Stimpson, 1865 are widely distributed in southern South America. They are abundant snails, numerically dominant in many lentic communities, and play an important role in the life cycles of parasites (Etchegoin 1997, Cazzaniga 2011, Merlo \& Etchegoin 2011, Merlo et al. 2014).

Shell morphology has been used to distinguish between different species belonging to the genus $\mathrm{He}$ - leobia; however, this approach is not foolproof, because of the typically minimal variation in shell characters. For this reason, the comparative study of other characters, such as penis and radula morphology, has recently been incorporated in taxonomic studies (Cazzaniga 2011).

However, according to previous studies (Gorbushin 1997, Probst \& Kuube 1999) in other host species, all of these morphological characters could be influenced by the presence of parasites. Parasitism by larval digeneans has been related to alterations in 
shell morphology and growth and to changes in the development of reproductive organs. These alterations could be a source of phenotypic variation among hosts (Minchella 1985, Gorbushin 1997, Morley 2006) and could therefore interfere with the correct identification at the genus or species level.

$H$. parchappii is one of the most representative species of the genus in freshwater bodies (streams, rivers, shallow lakes) in northern and central Argentina, Uruguay, and southern Brazil (Gaillard \& Castellanos 1976, Castellanos \& Landoni 1995). $H$. parchappii is a gonochoric species and is identified according to the morphology of the copulatory organ. The penis is elongated, moderately curved, and with black pigmentation on its convex side; the proximal portion has a wide base with 5 to 9 papillae in a continuous or interrupted row and with rounded or subquadrate edges. The distal portion narrows to an elongated conical tip, with 1 additional papilla on the convex side (Gaillard \& Castellanos 1976). H. parchappii has been recorded hosting up to 24 species of digeneans (Merlo 2014, Merlo et al. 2014), and we hypothesized that the copulatory organ could be altered by the presence of these parasites. We therefore examined penis morphology in order to evaluate the possible effect of larval digeneans on this structure and to determine whether parasites could interfere with the correct identification of species.

\section{MATERIALS AND METHODS}

Specimens of Heleobia parchappii were collected in April (2011) at Nahuel Rucá Lagoon $\left(37^{\circ} 37^{\prime} \mathrm{S}\right.$, $57^{\circ} 26^{\prime} \mathrm{W}$ ), in the province of Buenos Aires (Argentina). Snail identification was based on Gaillard \& Castellanos (1976). Snails were collected from the lagoon shoreline with the aid of sieves $(0.1 \mathrm{~mm} \times$ $0.1 \mathrm{~mm}$ ) and placed into plastic containers of $1.5 \mathrm{l}$ capacity for transportation. In the laboratory they were placed individually in plastic containers until further analysis.

Prior to dissection, a digital photograph was taken of each snail using a digital camera (Leica DFC 295). For the photography, each snail was oriented in the same way, with the shell aperture facing toward the camera lens. The total shell length (the distance from the apex to the anterior margin of the aperture) of each $H$. parchappii was measured to the nearest $0.01 \mathrm{~mm}$ using Leica Application Suite v3.6.

Each $H$. parchappii was dissected under a stereomicroscope (Leica DM 500) in order to determine the sex and to detect the presence of sporocysts, rediae, and cercariae. Only males were used for subsequent observations. For all males found after dissection, the total length of the penis was measured using Leica Application Suite v3.6, and the penial papillae were counted. Sporocysts, rediae, and cercariae were identified according to Martorelli (1986), Martorelli \& Etchegoin (1996), Etchegoin \& Martorelli (1998), and Merlo et al. (2014).

Prevalence for each digenean species was calculated as: (number of male snails infected with species i/ total number of male snails examined) $\times 100$, and total prevalence was calculated as: (number of parasitized snails/number of collected snails) $\times 100$.

Statistical analyses were performed only for digenean species with prevalences higher than $10 \%$; by this criterion, 3 out 9 digenean species identified were suitable for analysis (see 'Results'). Two analyses of covariance (ANCOVA) were used to test the effect of digenean species on penis length and number of penial papillae. Each digenean species and non-parasitized $H$. parchappii were used as categorical factors. H. parchappii penis length and the number of penial papillae were used as dependent variables, and $H$. parchappii body length was used as a continuously controlled covariable. When the slopes were not equal (heterogeneous), $a$ posteriori Tukey tests were used for further comparisons between digenean species and non-parasitized snails (Zar 2009). H. parchappii shell length, penis length, and number of papillae were transformed according to the formula $\ln (x+1)$ to meet the assumptions of each analysis. All analyses was carried out using ' $R$.'

\section{RESULTS}

In total, 700 specimens of Heleobia parchappii were collected (505 females and 195 males). In male specimens, 9 species of digeneans were found, with a total prevalence in males of $45.13 \%$. Each $H$. parchappii host was parasitized by only 1 species of digenean (no double infections were found). Only 3 out 9 digenenan species (Microphallus szidati, $M$. simillimus, and Notocotylidae sp. 1) showed prevalences higher than $10 \%$. Individual prevalences of the remaining species did not exceed $3 \%$ (Table 1 ).

For statistical analysis, only 4 groups were considered: (1) males without parasites (Nop), (2) males infected with M. simillimus (Ms), (3) males infected with M. szidati (Msz), and (4) males infected with Notocotylidae sp. 1 (Nsp). 
Table 1. Prevalence (Prev.) and detailed list of families and species/morphological type of larval digeneans parasitizing male Heleobia parchappii

\begin{tabular}{|llcl|}
\hline Family & Species/morphological type & Prev. (\%) & Reference \\
\hline Heterophyidae & Pleurolophocercaria III & 1.03 & Martorelli \& Etchegoin (1996) \\
& Cercaria, Heterophyidae sp. 8 & 2.56 & Merlo et al. (2014) \\
Hemiuridae & Cercaria, Hemiuridae sp.1 & 1.54 & Merlo (2014) \\
Plagiorchiidae & Xiphidiocercaria sp. 3 & 1.03 & Merlo et al. (2014) \\
Psilostomatidae & Cercaria, aff. Psilochasmus & 1.03 & Etchegoin \& Martorelli (1998) \\
Haploporidae & Cercaria, Haploporidae sp. 3 & 0.51 & Merlo et al. (2014) \\
Microphallidae & Microphallus simillimus (Travassos, 1920) & 10.26 & Etchegoin (1997) \\
& Microphallus szidati Martorelli, 1986 & 11.79 & Martorelli (1986), Etchegoin (1997) \\
Notocotylidae & Notocotylidae sp. 1 & 12.82 & Etchegoin \& Martorelli (1998) \\
& Redia + Sporocyst & 2.56 & \\
Overall prevalence & & 45.13 & \\
\hline
\end{tabular}

The groups Nop, Ms, and Msz showed a significant positive linear relationship between shell length and penis length (Fig. 1). ANCOVA revealed an interaction between the covariable and the categorical factor $\left(F_{2,46}=7.10 ; \mathrm{p}<0.01\right)$; thus, the slopes of the 3 groups were statistically different. The slope of Nop was higher than that of Ms and Msz (Tukey test, p < 0.01 , in all cases), while no significant difference was observed between Ms and Mz (Tukey test, $\mathrm{p}=$ 0.36). Conversely, the group Nsp did not show a significant relationship between shell length and penis length. Finally, none of the groups (Nop, Ms, Msz,

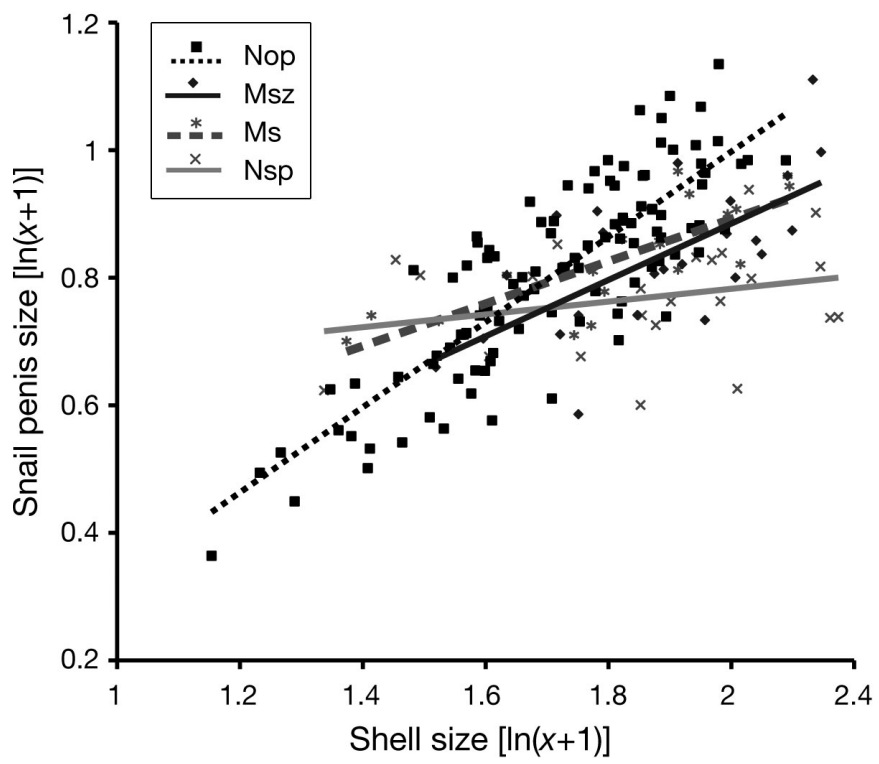

Fig. 1. Comparison of penis length between uninfected Heleobia parchappii (Nop) and H. parchappii infected with Microphallus szidati (Msz), M. simillimus (Ms), and Notocotylidae sp. 1 (Nsp), with $H$. parachappii shell length as a covariable and Nsp) showed a significant relationship between the number of penial papillae and shell length, for which ANCOVA to compare linear regressions was not performed.

\section{DISCUSSION}

Males of Heleobia parchappii were parasitized by 9 species of digeneans, with a total prevalence of about $45 \%$. Regarding the phenotypic characteristics of the penis (length and number of papillae), we observed that penis length increased with increased snail length in snails that were not parasitized as well as in those that were parasitized by Microphallus szidati and M. similimus. However, this increase was lower in $H$. parchappii infected with $M$. szidati and M. similimus. Conversely, the lack of correlation between shell length and penis length in snails infected with Notocotylidae sp. 1 could be interpreted as a cessation of growth of the penis. Regarding the number of penial papillae, we found no relationship between the number of papillae and shell length in any of the groups studied.

Infection by parasites has been shown to influence many aspects of host phenotype, including physiology (Thompson 1997), life history (Minchella 1985), behavior (Moore 2002), sexually selected traits (Zuk 1992), and morphology (McCarthy et al. 2004). These modifications of the phenotypic characteristics are merely by-products of infection or adaptations for the parasites to complete their life cycles (Minchella 1985, McCarthy et al. 2004). The digeneans typically have complex life cycles with different larval stages that parasitize a first intermediate host (generally mollusks), a second intermediate host (invertebrates 
or vertebrates), and then finally maturing as adults in the definitive host (vertebrates). Host specificity, in the first intermediate host, is one of the characteristic features of larval digenean-mollusk associations, with most digenean species able to develop in a single family or species of molluscan hosts (Galaktionov \& Dobrovolskij 2013).

As mentioned above, penis growth stopped in $H$. parchappii infected with Notocotylidae sp. 1, while snails infected with $M$. similimus and $M$. szidati had a lower penis growth rate in relation to non-parasitized snails. Differences in growth rate and reduced penis length associated with larval digeneans belonging to the families Notocotylidae and Microphallidae were also observed in Hydrobia ulvae (Gorbushin 1997), and members of the families Notocotylidae and Microphallidae have been observed causing castration in H. ulvae (Gorbushin 1997). Digenean species differ in the intra-molluscan stages of their life cycles; Notocotylidae present rediae and cercariae, while digeneans belonging to the Microphallidae present the sporocyst stage. The most relevant difference between rediae and sporocysts is their means of nutrient acquisition. Rediae have a digestive system (mouth, pharynx, and short saccular gut) and actively feed on the cell tissue of Cochliopidae, whereas sporocysts absorb all nutrients directly through the tegument. An additional difference is the limited mobility of sporocysts within the host. Consequently, although both stages cause damage to host organs, rediae can cause greater damage or harm within a shorter infection time (Sousa \& Gleason 1989, Probst \& Kube 1999, Sorensen \& Minchella 2001). In the case of $H$. parchappii, the 3 species of digeneans considered in this study invade the gonad and digestive gland of the snail (Martorelli 1986, Etchegoin 1997, Etchegoin \& Martorelli 1998), and thus are a potential cause of castration. All of these combined factors could explain the null or lower rate of penis growth in relation to body growth of the host.

The lack of relationship between the number of penial papillae and shell length of $H$. parchappii coincides with that observed by Cazzaniga (1982), who estimated that the number of penis papillae stabilizes at a snail body length of $3 \mathrm{~mm}$. Given that snails below $4 \mathrm{~mm}$ in body length are rarely infected by larval digeneans (Merlo 2014), the number of papillae would not be affected by parasites.

Since shell morphology is an ambiguous approach to discriminate between species in the genus Heleobia (Cazzaniga 2011), other characters like morphology of the penis are used to advance our knowledge of the systematics of this group, although this organ presents intraspecific variation (Gaillard \& Castellanos 1976, Cazzaniga 1982). According to our results, the number of penial papilla of $H$. parchappii is a more stable character for species identification, as it appears uninfluenced by infection with larval digeneans. Therefore, further studies on the development and intra-specific variation in the number of penial papilla should be central in the diagnosis and taxonomic identification of new species within the family Cochliopidae as well as in previously described species.

Acknowledgements. We thank Pedro Urrutia for allowing us to work in Nahuel Rucá Lagoon. We greatly appreciate the valuable comments and suggestions from 3 anonymous reviewers. J.A.E., M.P., and M.J.M. are members of Consejo Nacional de Investigaciones Científicas y Técnicas (CONICET), Argentina. This work was supported by CONICET (PIP 112- 201101- 00113 to J.A.E.) and Universidad Nacional de Mar del Plata (grant number 15/E722 EXA 771/16 to J.A.E.).

\section{LITERATURE CITED}

Castellanos ZJA, Landoni N (1995) Moluscos Pelecypoda y Gastropoda. In: Lopretto E, Tell G (eds) Ecosistemas de aguas continentales, metodología para su estudio. Ediciones Sur, La Plata, p 759-801

Cazzaniga NJ (1982) Notas sobre hidrobidos argentinos. 5. Conquiliometria de Littoridina parchappii (D'Orbigny, 1835) (Gastropoda Rissoidea) referida a su ciclo de vida en poblaciones australes. Iheringia (Zool) 61:97-118

Cazzaniga NJ (2011) Heleobia Stimpson, 1865: Taxonomía. In: Cazzaniga NJ (ed) El género Heleobia (Caenogastropoda: Cochliopidae) en América del Sur. Amici Molluscarum, Número especial, Santiago de Chile, p 14-17

Etchegoin JA (1997) Sistemas parasitarios presentes en la albufera Mar Chiquita. PhD dissertation, Universidad Nacional de Mar del Plata

Etchegoin JA, Martorelli SR (1998) Nuevas cercarias en Heleobia conexa (Mollusca: Hydrobiidae) de la albufera Mar Chiquita. Neotropica 44:41-50

Gaillard MC, Castellanos ZA (1976) Mollusca, Gasteropoda, Hydrobiidae. In: Ringuelet RA (ed) Fauna de agua dulce de la República Argentina. FECIC, Buenos Aires, p 1-39

Galaktionov KV, Dobrovolskij A (2013) The biology and evolution of trematodes: an essay on the biology, morphology, life cycles, transmissions, and evolution of digenetic trematodes. Kluwer Academic Publishers, Dordrecht

Gorbushin AM (1997) Field evidence of trematode-induced gigantism in Hydrobia spp. (Gastropoda: Prosobranchia). J Mar Biol Assoc UK 77:785-800

Martorelli SR (1986) Estudio sistemático y biológico de un digeneo perteneciente a la familia Microphallidae Travassos, 1920. I: Microphallus szidati sp. nov. parásito intestinal de Rallus sanguinolentus sanguinolentus (Aves: Rallidae) e Himantopus melanurus (Aves: Recurvirrostridae). Rev Iber Parasitol 46:373-378

Martorelli SR, Etchegoin JA (1996) Cercarias de la superfamilia Opisthorchioidae en Heleobia conexa (Mollusca: 
Hydrobiidae) de la albufera de Mar Chiquita. Neotropica 42:61-68

McCarthy HO, Fitzpatrick SM, Irwin SWB (2004) Parasite alteration of host shape: a quantitative approach to gigantism helps elucidate evolutionary advantages. Parasitology 128:7-14

Merlo MJ (2014) Ecología de las comunidades de digeneos larvales en hospedadores moluscos del género Heleobia Stimpson, 1865 (Gastropoda: Rissooidea). PhD dissertation, Universidad Nacional de Mar del Plata

Merlo MJ, Etchegoin JA (2011) Testing temporal stability of the larval digenean community in Heleobia conexa (Mollusca: Cochliopidae) and its possible use as an indicator of environmental fluctuations. Parasitology 138:249-256

Merlo MJ, Parietti M, Etchegoin JA (2014) Digeneos larvales de Heleobia parchappii y de Heleobia australis en ambientes dulceacuícolas y estuariales de la provincia de Buenos Aires (Argentina). Rev Argent Parasitol 2:14-21

Minchella DJ (1985) Host life-history variation in response to parasitism. Parasitology 90:205-216

Moore J (2002) Parasites and the behavior of animals. Oxford University Press, New York, NY

Morley NJ (2006) Parasitism as a source of potential distor-

Editorial responsibility: Stephen Feist,

Weymouth, UK tion in studies on endocrine disrupting chemicals in molluscs. Mar Pollut Bull 52:1330-1332

Probst S, Kube J (1999) Histopathological effects of larval trematode infections in mudsnails and their impact on host growth: What causes gigantism in Hydrobia ventrosa (Gastropoda: Prosobranchia)? J Exp Mar Biol Ecol 238:49-68

Sorensen RE, Minchella DJ (2001) Snail-trematode life history interactions: past trends and future directions. Parasitology 123(Suppl):S3-S18

Sousa WP, Gleason M (1989) Does parasitic infection compromise host survival under extreme environmental conditions? The case for Cerithidea californica (Gastropoda: Prosobranchia). Oecologia 80:456-464

Thompson SN (1997) Physiology and biochemistry of snaillarval trematode relationships. In: Fried B, Graczyk TK (eds) Advances in trematode biology. CRC Press, Boca Raton, FL, p 149-196

Zar JH (2009) Biostatistical analysis, 5th edn. Pearson Education, Upper Saddle River, NJ

Zuk M (1992) The role of parasites in sexual selection: current evidence and future directions. Adv Stud Behav 21: $39-68$

Submitted: May 12, 2016; Accepted: November 28, 2016 Proofs received from author(s): January 22, 2017 